WSRC-TR-2000-00434

WSRC-TR-2000-00434

SRT-RPP-2000-00040

KEYWORDS:

Hanford River Protection Project Envelope B

Envelope $C$

Pretreatment

\title{
Material Corrosion and Plate-Out Test of Types 304L and 316L Stainless Steel
}

SAVANNAH RIVER TECHNOLOGY CENTER

Philip E. Zapp

Publication Date: January 2001

Westinghouse Savannah River Company

Savannah River Site

Aiken, SC 29808

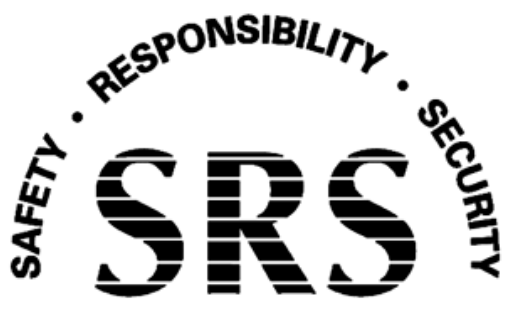

Prepared for the U.S. Department of Energy under Contract No. DE-AC0996SR18500 
This document was prepared in conjunction with work accomplished under Contract No.

DE-AC09-96SR18500 with the U.S. Department of Energy.

\section{DISCLAIMER}

This report was prepared as an account of work sponsored by an agency of the United States Government. Neither the United States Government nor any agency thereof, nor any of their employees, makes any warranty, express or implied, or assumes any legal liability or responsibility for the accuracy, completeness, or usefulness of any information, apparatus, product or process disclosed, or represents that its use would not infringe privately owned rights. Reference herein to any specific commercial product, process or service by trade name, trademark, manufacturer, or otherwise does not necessarily constitute or imply its endorsement, recommendation, or favoring by the United States Government or any agency

thereof. The views and opinions of authors expressed herein do not necessarily state or reflect those of the United States Government or any agency thereof.

This report has been reproduced directly from the best available copy.

Available for sale to the public, in paper, from: U.S. Department of Commerce, National Technical Information Service, 5285 Port Royal Road, Springfield, VA 22161, phone: (800)

553-6847, fax: (703) 605-6900, email: orders@ntis.fedworld.gov online ordering: http://www.ntis.gov/ordering.htm

Available electronically at http://www.doe.gov/bridge

Available for a processing fee to U.S. Department of Energy and its contractors, in paper, from: U.S. Department of Energy, Office of Scientific and Technical Information, P.O. Box 62, Oak Ridge, TN 37831-0062, phone: (865 ) 576-8401, fax: (865) 576-5728, email: reports@ adonis.osti.gov 


\section{Contents}

Summary

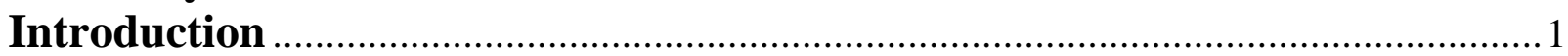

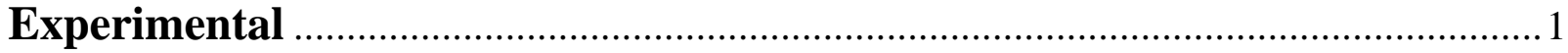

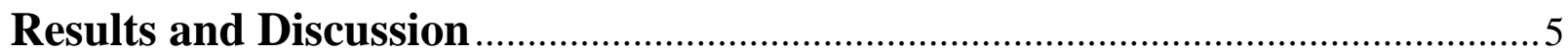

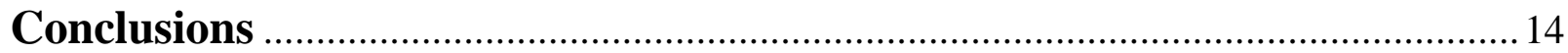

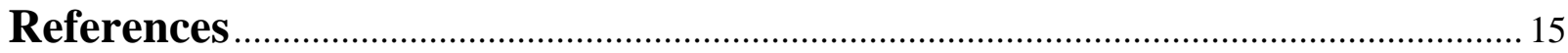




\section{SUMMARY}

Corrosion and plate-out tests were performed on 304L and 316L stainless steel in pretreated Envelope B and Envelope $\mathrm{C}$ solutions. Flat coupons of the two stainless steels were exposed to $100^{\circ} \mathrm{C}$ liquid and to $74^{\circ} \mathrm{C}$ and $88^{\circ} \mathrm{C}$ vapor above the solutions for 61 days. No significant corrosion was observed either by weight-loss measurements or by microscopic examination. Most coupons had small weight gains due to plate-out of solids, which remained to some extent even after 24-hour immersion in $1 \mathrm{~N}$ nitric acid at room temperature. Plate-out was more significant in the Envelope B coupons, with film thickness from less than 0.001 in. to 0.003 -inches.

Radioactive contamination levels were assayed with gamma spectroscopy. Envelope B coupons were contaminated with cesium-137 only. The acid cleaning of Envelope B coupons that had been in contact with liquid yielded a decontamination factor of between 2 and 7 . Additional mechanical cleaning increased the overall decontamination factors from 9 to 91 . Envelope $\mathrm{C}$ coupons had lower levels of contamination (in conjunction with less plate-out) that were comprised of cesium-137, cobalt-60, europium-154 and -155, and americium-241. Decontamination factors of several hundred were obtained after acid and mechanical cleaning.

\section{INTRODUCTION}

The Hanford Site River Protection Project (RPP) is investigating the effects of contacting candidate materials (i.e. alloy C-22, 304L and 316L stainless steels) with LAW solutions [1]. The Pacific Northwest National Laboratory (PNNL) and the Savannah River Technology Center (SRTC) are jointly conducting this assessment for the RPP. The PNNL conducted immersion tests with coupons of alloy C-22, 304L and 316 stainless steels and pretreated tank 241-AN-107, tank 241-AW-101 LAW solutions, as well as caustic leachate from treatment of a tank 241-C-104 high-level waste sample [2]. The combined PNNL and SRTC work scope completes the corrosion testing requested by the RPP.

Laboratory coupon immersion tests were conducted at SRTC to investigate the effects of two actual lowactivity Hanford Site waste solutions on two candidate materials of construction, types 304L and 316L stainless steel. The waste solutions were pretreated low-activity waste solutions identified as Envelope B and Envelope C, described below. The objectives of the testing were (1) to measure the uniform corrosion rate of the materials of construction under different exposure conditions, and (2) to assess the ability of an acid cleaning solution to remove plated-out solids.

\section{EXPERIMENTAL}

In accordance with the program test plan, coupon immersion tests were conducted in small volumes of pretreated Envelope B and C solutions [3]. Separate tests were conducted for each stainless steel in each pretreated solution. Only $250 \mathrm{~mL}$ of Envelope B solution were available for testing, so special glass flasks were fabricated for testing both envelopes. These flasks permitted full immersion of the standard 1-in. by 2 -in. flat specimens prescribed in the test plan. The flasks were equipped with reflux condensers and with polyethylene and polytetrafluoroethylene rods on which to suspend the coupons (Figure 1). (Fluorinated plastic liners were not used in the flasks because the solutions were lower in hydroxide concentration than originally planned.) Coupons were also suspended for partial immersion in liquid and for exposure to vapor immediately above the liquid (termed the vapor position) and to vapor at the entrance to the condenser (termed the condenser position).

Duplicate coupons were exposed in the full-liquid, partial-liquid, and vapor positions. The flasks were heated on hot plates to bring the solution temperature to $100 \pm 3^{\circ} \mathrm{C}$. The temperature of the vapor immediately above the liquid was $88 \pm 3^{\circ} \mathrm{C}$, and the temperature at the inlet to the condenser was $74 \pm 3^{\circ} \mathrm{C}$. Chilled water was recirculated through the condensers, which were linked in series. Thermocouples were used to measure the liquid temperature. The hot plates were adjusted manually to maintain temperature. Distilled water was added weekly to restore evaporative losses. 
The four sets of apparatus were located in a radiological hood for radioactive contamination control. Strict material control was required because of the listed-waste nature of the Envelope B and C solutions. Each condenser exhausted to the hood through a glass tube containing about 80 grams of activated carbon to capture hazardous off-gas species. Shallow beakers were placed beneath the flasks as secondary containment around the beakers, and the hotplates were placed in glass pans for additional spill control.

The flat test coupons were of types 304L and 316L stainless steel obtained from Metal Samples Inc., Munford, AL. The $304 \mathrm{~L}$ coupons were $1 / 8$ in. thick and the $316 \mathrm{~L}$ coupons were $1 / 16$ in. thick, and were used in their as-received, 600-grit-finish condition. The coupons were degreased in acetone, photographed, and weighed prior to emplacement in the test flasks. Figure 2 shows photographs of a typical pair of coupons before insertion into the test flask.

The Envelope B test solution was obtained from a 3-liter waste sample received from the Hanford Site. The sample was diluted and treated by ion exchange to remove cesium and technetium, then concentrated by evaporation to a sodium molarity of about $2[4,5]$. The Envelope $\mathrm{C}$ sample was received from the Hanford Site, diluted, and treated to remove strontium and transuranics by a precipitation process [6]. The filtered product was then treated by ion exchange to remove cesium and technetium. The sample received for corrosion testing was nominally 5 Molar in sodium. The compositions of the tests solutions are shown in Table 1. About $125 \mathrm{~mL}$ of each envelope was used in a test flask. Although the ASTM recommends 30 $\mathrm{mL}$ of test solution per square centimeter of coupon area in immersion tests, the present configuration (with 2 coupons each having about $30 \mathrm{~cm}^{2}$ surface area fully immersed) was considered acceptable given the expected low corrosion rates.

The test coupons were exposed for 61 days. Upon completion of the immersion, the coupons were subjected to a decontamination procedure to assess the feasibility of removing plated-out solids. The decontamination procedure was a 24 -hour immersion in $1 \mathrm{~N}$ nitric acid at room temperature. Before decontamination the radionuclide content on each coupon was assessed by a gamma radiation scan, which identified radionuclides and their quantities. The gamma scans were performed again after the 24-hour acid immersion, and finally after a subsequent mechanical cleaning step. The mechanical cleaning step consisted of scraping with plastic-tipped tweezers and wiping with water-soaked paper tissues. Finally, the coupons were weighed again to determine the rate of any corrosion and photographed. The coupons were examined through optical microscopy to assess localized corrosion (pitting). 


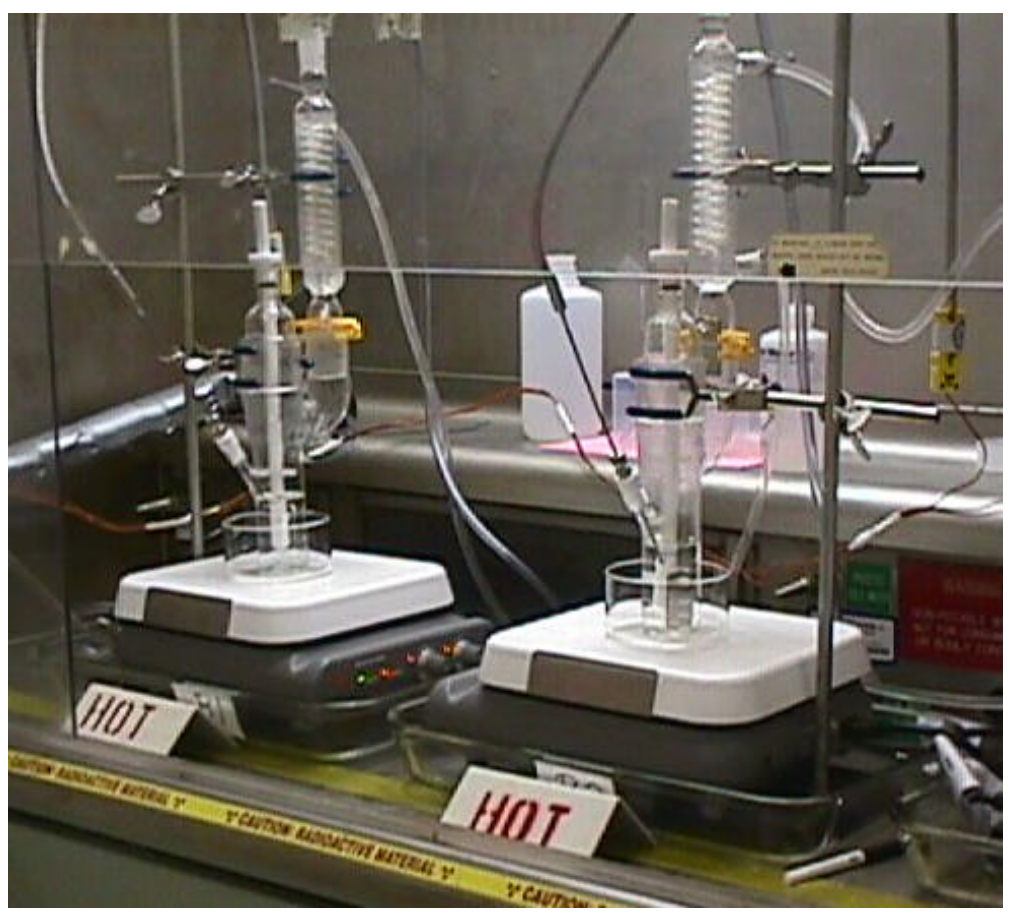

Figure 1. Apparatus for the corrosion and plate-out tests, before addition of solution and placement of coupons.
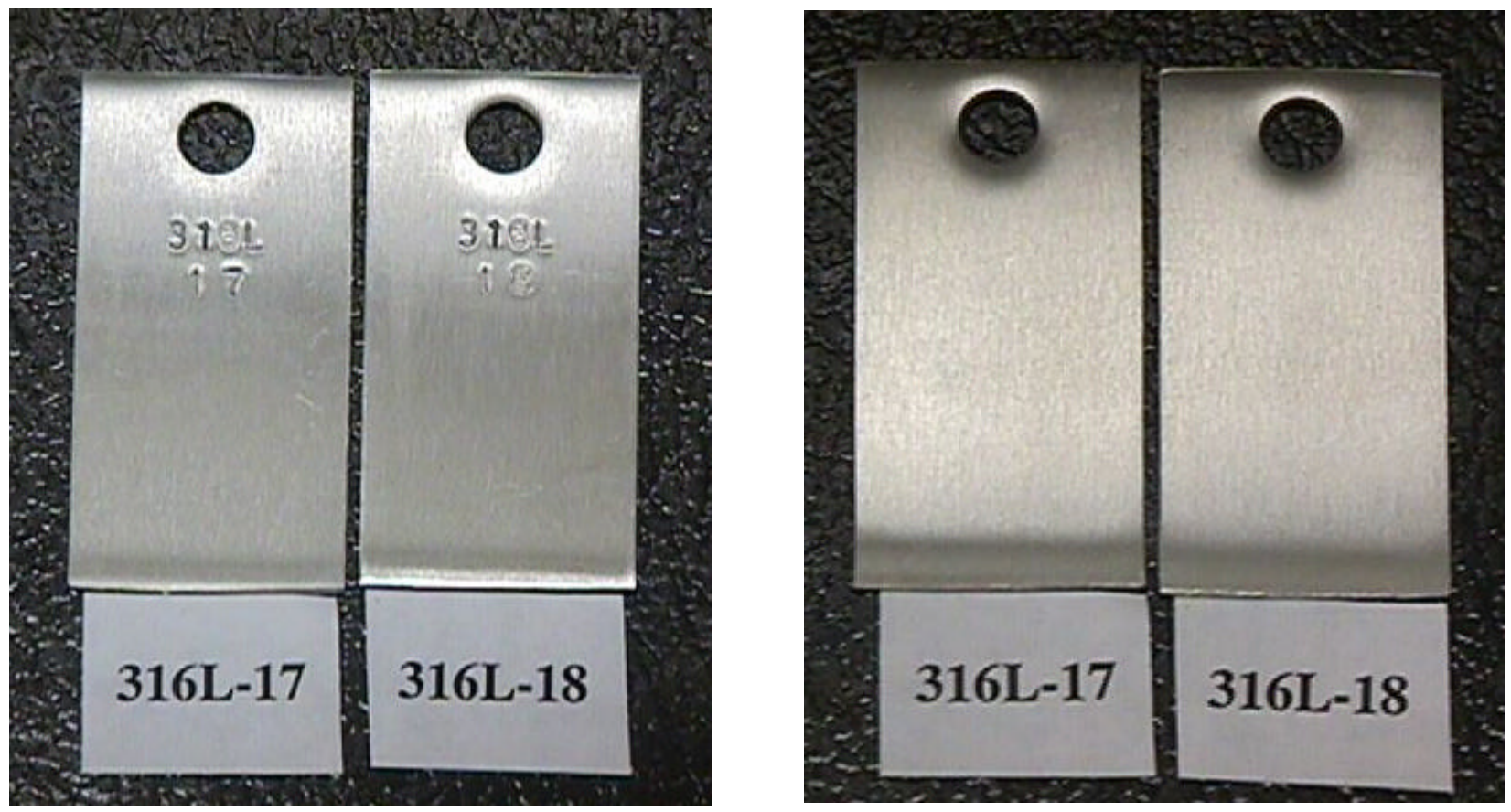

Figure 2. Front and rear views of 1 in. by 2 in. by $1 / 16$ in. flat type 316 stainless steel coupons before test. 
Table 1

Chemical Analyses of Envelope B and C Solutions

\begin{tabular}{|c|c|c|}
\hline \multicolumn{3}{|l|}{ Radionuclides } \\
\hline Cesium-137 (uCi/mL) & 0.647 & 0.0528 \\
\hline Cobalt-60 (uCi/mL) & $<0.0016$ & 0.0399 \\
\hline Europium-154 (uCi/mL) & $<0.0068$ & 0.0342 \\
\hline Europium-155 (uCi/mL) & $<0.0090$ & 0.0232 \\
\hline Technitium-99 (ug/L) & 0.0076 & not reported \\
\hline Plutonium-238 (disintegrations/min/mL) & 486 & not reported \\
\hline Plutonium-239/240 (disintegrations $/ \mathrm{min} / \mathrm{mL}$ & L) 1049 & not reported \\
\hline mass 230 & $<0.0951$ & $<0.0033$ \\
\hline mass 231 & $<0.0951$ & $<0.0033$ \\
\hline mass 232 (Th) & 37.3 & 1.47 \\
\hline mass 233 & $<0.0951$ & $<0.0033$ \\
\hline mass $234(U)$ & $<0.0951$ & $<0.0033$ \\
\hline mass $235(U)$ & 27.6 & 0.0096 \\
\hline mass $236(U)$ & $<0.0951$ & $<0.0033$ \\
\hline mass $237(\mathrm{~Np})$ & 136 & 0.0883 \\
\hline mass 238 (Pu \& U) & 2339 & 0.903 \\
\hline mass $239(\mathrm{Pu})$ & $<0.0502$ & 0.0145 \\
\hline mass $240(\mathrm{Pu})$ & $<0.0502$ & $<0.0033$ \\
\hline mass 241 (Am \& Pu) & $<0.0502$ & 0.0075 \\
\hline mass $242(\mathrm{Pu})$ & $<0.0502$ & $<0.0033$ \\
\hline mass $243(\mathrm{Am})$ & $<0.0502$ & $<0.0033$ \\
\hline mass $244(\mathrm{Cm})$ & $<0.0502$ & $<0.0033$ \\
\hline mass $245(\mathrm{Cm})$ & $<0.0502$ & $<0.0033$ \\
\hline mass 246 & $<0.0502$ & $<0.0033$ \\
\hline \multicolumn{3}{|l|}{ Atomic Absorption (mg/L) } \\
\hline Potassium & 2584 & 951.0 \\
\hline Sodium & 50888 & not reported \\
\hline Arsenic & 329 & 0.255 \\
\hline Selenium & 407 & 0.142 \\
\hline Mercury & $<0.11$ & $<0.019$ \\
\hline Total Uranium & not reported & $<1.00$ \\
\hline Uranium - (mg/L) by Chem check & 1.610 & not reported \\
\hline \multicolumn{3}{|l|}{ Ion Chromatography (mg/L) } \\
\hline Nitrate & 13388 & 85942 \\
\hline Nitrite & 26147 & 36218 \\
\hline Phosphate & 245.1 & 2196 \\
\hline Sulfate & 13287 & 5475 \\
\hline Oxalate & 2401 & 1067 \\
\hline Formate & $<111$ & 4567 \\
\hline Chloride (by IC) & 66.8 & 1575 \\
\hline Fluoride ( by IC) & 869 & 766 \\
\hline Chloride (by Ion Specific Electrode) & 182 & 200 \\
\hline Fluoride (by Ion Specific Electrode) & 863 & $<82.3$ \\
\hline
\end{tabular}




\begin{tabular}{|c|c|c|}
\hline \multicolumn{3}{|c|}{ Emission Spectroscopy (mg/L) } \\
\hline Aluminum & 402 & 5360 \\
\hline Boron & 1.14 & 13.4 \\
\hline Barium & 1.34 & $<0.254$ \\
\hline Calcium & 0.567 & 111 \\
\hline Cadmium & $<0.067$ & 19.9 \\
\hline Cobalt & 0.139 & 1.557 \\
\hline Chromium & 533 & 70.3 \\
\hline Copper & $<0.0668$ & 3.583 \\
\hline Iron & $<0.0668$ & 1.931 \\
\hline Lanthanum & $<0.245$ & $<1.351$ \\
\hline Lithium & $<0.0446$ & $<0.270$ \\
\hline Magnesium & $<0.0223$ & $<0.093$ \\
\hline Manganese & $<0.0223$ & 0.798 \\
\hline Molybdenum & 43.2 & 21.48 \\
\hline Sodium & 41238 & 111515 \\
\hline Nickel & $<0.156$ & 124 \\
\hline Phosphorus & 139 & 687 \\
\hline Lead & 1.17 & 44.4 \\
\hline Silicon & 99.7 & 33.9 \\
\hline Tin & 7.49 & 11.0 \\
\hline Strontium & $<0.0223$ & 126 \\
\hline Technetium & not reported & 2.52 \\
\hline Titanium & $<0.0446$ & $<0.358$ \\
\hline Vanadium & 0.362 & $<0.610$ \\
\hline Zinc & 0.434 & 1.29 \\
\hline Zirconium & not reported & $<0.399$ \\
\hline Aluminate (Moles/Liter) & $<0.0200$ & not reported \\
\hline Free Hydroxide (Moles/Liter) & 0.223 & 1.24 \\
\hline Carbon (mg/L) & & \\
\hline Inorganic (TIC) & 8616 & 5838 \\
\hline Organic (TOC) & 8344 & 11399 \\
\hline density $(\mathrm{g} / \mathrm{mL})$ & 1.097 & 1.23 \\
\hline wt\% Total solids & 12.52 & 31.5 \\
\hline wt.\% suspended solids & $<0.0044$ & $<0.002$ \\
\hline
\end{tabular}

\section{RESULTS AND DISCUSSION}

\section{Corrosion Measurements}

Uniform corrosion rates are calculated from weight loss measurements of exposed coupons. Table 2 lists the initial weights, the final weights after the two cleaning steps, and the weight changes for all coupons. (The initial weights of the clean coupons were measured with a calibrated five-place balance; final weights had to be measured on a calibrated four-place balance located in the radiological hood.) As the table shows, most coupons in this experiment experienced a weight gain rather than a weight loss, due to the adherence of plated-out solids despite the cleaning steps. Therefore corrosion rates were calculated only for the few coupons where a weight loss was recorded. Usually these coupons were those in the vapor or condenser positions, where the absence of contact with liquid made plate-out less likely. The uniform corrosion rates shown are all insignificantly small, not exceeding 0.012 mils per year $(0.3-\mu \mathrm{m} / \mathrm{yr}$.), which is to be expected in the highly alkaline test solutions of Envelopes B and C. 
The two control coupons listed at the bottom of Table 2 were exposed to the same $1 \mathrm{~N}$ nitric acid cleaning solution for the same 24-period as the Envelope B coupons. The 304L coupon showed a weight loss due to cleaning, while the $316 \mathrm{~L}$ coupon showed a weight gain, perhaps as a result of contact with a coupon with deposits. The weight loss translated to a low corrosion rate of 0.1 mil per year. Thus the cleaning step was apparently more aggressive than the test exposure itself.

The weight gains on the test coupons are attributed to the retention of tightly adhering solids. Plated-out solids on coupons with weight gains may hide metal weight loss due to corrosion. The test coupons were examined with optical microscopy for visible indications of corrosion. When they do corrode, passive alloys such as these stainless steel typically degrade by localized corrosion modes, as the passive film is breached under pitting or crevice corrosion, for example. Microscopic examination in fact revealed no evidence of pitting or crevice corrosion. Apart from some staining of the coupons, the surfaces remained shiny. The polishing marks from the original 600-grit finish were still sharp and prominent (typically shown in Figure 3). Visual examination thus revealed that there was no localized corrosion. The shiny surface condition is consistent with the absence of significant weight loss. 
Table 2

Weight Measurements and Corrosion Rates*

\begin{tabular}{|c|c|c|c|c|c|c|c|}
\hline $\begin{array}{l}\text { Envelope B } \\
\text { Coupon No. }\end{array}$ & Position & $\begin{array}{c}\text { Initial } \\
\text { Weight, g }\end{array}$ & $\begin{array}{c}\text { Final } \\
\text { Weight, } \mathbf{g}\end{array}$ & $\begin{array}{c}\text { Weight } \\
\text { Change, g }\end{array}$ & $\begin{array}{l}\text { Area, } \\
\mathrm{cm}^{\wedge} 2\end{array}$ & $\begin{array}{l}\text { Elapsed } \\
\text { Time, Hrs }\end{array}$ & $\begin{array}{c}\text { mils per } \\
\text { year }\end{array}$ \\
\hline $304 L-21$ & Condenser & 27.70739 & 27.8081 & -0.1007 & 30.55 & 1464 & - \\
\hline 304L-22 & Vapor & 28.11807 & 28.1237 & -0.0056 & 30.55 & 1464 & - \\
\hline 304L-23 & Vapor & 28.47480 & 28.4752 & -0.0004 & 30.55 & 1464 & - \\
\hline $304 L-24$ & Partial Liquid & 28.03165 & 28.0403 & -0.0086 & 30.55 & 1464 & - \\
\hline $304 L-25$ & Partial Liquid & 28.16975 & 28.1794 & -0.0097 & 30.55 & 1464 & - \\
\hline $304 L-26$ & Full Liquid & 28.14463 & 28.1469 & -0.0023 & 30.55 & 1464 & - \\
\hline $304 L-27$ & Full Liquid & 28.16062 & 28.1733 & -0.0127 & 30.55 & 1464 & - \\
\hline 316L-03 & Condenser & 14.28900 & 14.2880 & 0.0010 & 28.15 & 1464 & 0.010 \\
\hline $316 \mathrm{~L}-04$ & Vapor & 14.31780 & 14.3242 & -0.0064 & 28.15 & 1464 & - \\
\hline $316 \mathrm{~L}-06$ & Vapor & 14.29614 & 14.2986 & -0.0025 & 28.15 & 1464 & - \\
\hline $316 \mathrm{~L}-07$ & Partial Liquid & 14.33526 & 14.3453 & -0.0100 & 28.15 & 1464 & - \\
\hline 316L-08 & Partial Liquid & 14.27639 & 14.2828 & -0.0064 & 28.15 & 1464 & - \\
\hline $316 \mathrm{~L}-10$ & Full Liquid & 14.30415 & 14.3106 & -0.0065 & 28.15 & 1464 & - \\
\hline $316 \mathrm{~L}-20$ & Full Liquid & 14.28111 & 14.3129 & -0.0318 & 28.15 & 1464 & - \\
\hline
\end{tabular}

\begin{tabular}{|c|c|c|c|c|c|c|c|}
\hline $\begin{array}{l}\text { Envelope C } \\
\text { Coupon No. }\end{array}$ & Position & $\begin{array}{c}\text { Initial } \\
\text { Weight, g }\end{array}$ & $\begin{array}{c}\text { Final } \\
\text { Weight, g }\end{array}$ & $\begin{array}{c}\text { Weight } \\
\text { Change, g }\end{array}$ & $\begin{array}{l}\text { Area, } \\
\mathrm{cm}^{\wedge} 2\end{array}$ & $\begin{array}{l}\text { Elapsed } \\
\text { Time, Hrs }\end{array}$ & $\begin{array}{c}\text { mils per } \\
\text { year }\end{array}$ \\
\hline $304 \mathrm{~L}-11$ & Condenser & 29.25841 & 29.2580 & 0.0004 & 30.55 & 1464 & 0.004 \\
\hline $304 L-12$ & Vapor & 29.48678 & 29.4855 & 0.0013 & 30.55 & 1464 & 0.012 \\
\hline $304 L-13$ & Vapor & 29.43131 & 29.4314 & -0.0001 & 30.55 & 1464 & - \\
\hline $304 L-14$ & Partial Liquid & 29.31114 & 29.3156 & -0.0045 & 30.55 & 1464 & - \\
\hline $304 L-15$ & Partial Liquid & 29.46739 & 29.4731 & -0.0057 & 30.55 & 1464 & - \\
\hline $304 L-16$ & Full Liquid & 29.46070 & 29.4614 & -0.0007 & 30.55 & 1464 & - \\
\hline $304 L-17$ & Full Liquid & 29.35073 & 29.3520 & -0.0013 & 30.55 & 1464 & - \\
\hline $316 L-11$ & Condenser & 14.20880 & 14.2085 & 0.0003 & 28.15 & 1464 & 0.003 \\
\hline $316 L-14$ & Vapor & 14.19978 & 14.2007 & -0.0009 & 28.15 & 1464 & - \\
\hline $316 L-15$ & Vapor & 14.26658 & 14.2686 & -0.0020 & 28.15 & 1464 & - \\
\hline $316 L-16$ & Partial Liquid & 14.29132 & 14.2921 & -0.0008 & 28.15 & 1464 & - \\
\hline $316 \mathrm{~L}-17$ & Partial Liquid & 14.27553 & 14.2766 & -0.0011 & 28.15 & 1464 & - \\
\hline $316 L-18$ & Full Liquid & 14.09963 & 14.0995 & 0.0001 & 28.15 & 1464 & 0.001 \\
\hline $316 L-19$ & Full Liquid & 14.31190 & 14.3135 & -0.0016 & 28.15 & 1464 & - \\
\hline 304L Control & $\mathrm{N} / \mathrm{A}$ & 28.54367 & 28.5435 & 0.0002 & 30.55 & 24 & 0.101 \\
\hline 316L Control & $\mathrm{N} / \mathrm{A}$ & 14.17793 & 14.1781 & -0.0002 & 28.15 & 24 & \\
\hline
\end{tabular}

Corrosion Rate, mils per ear

*Corrosion rates calculated for those test coupons with weight losses only. 

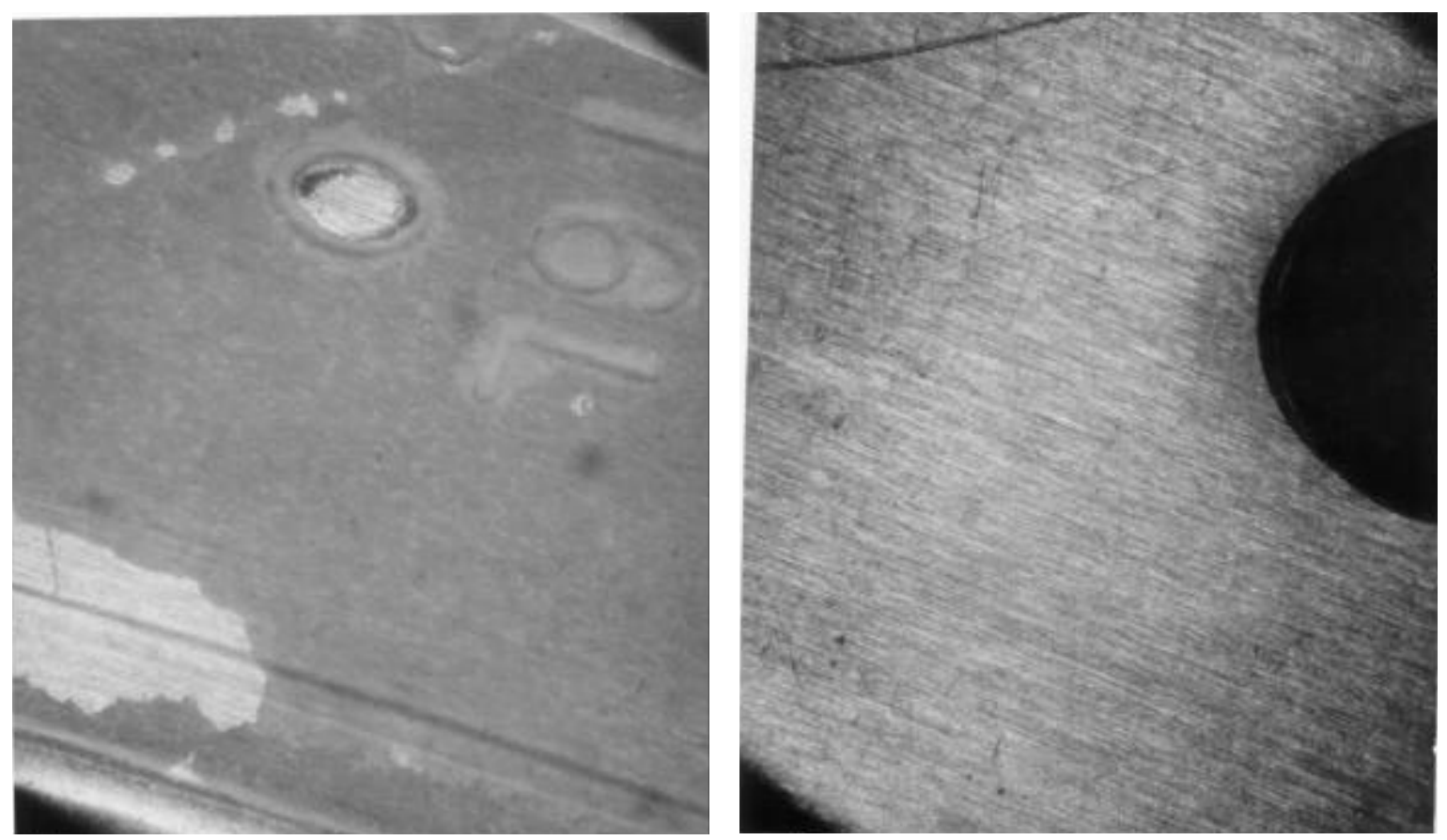

Figure 3. Front (left, mostly covered with plated-out solids) and rear (right, ) views of coupon 316L-20 after acid and mechanical cleaning, original magnification 7.8X. The thickness of the plated-out solids is about 0.003 in.

\section{Plate-out of Solids and Coupon Cleaning}

There was considerable plate-out of solids in hard, thin films on coupons that were in contact with liquid. Thin films of solids also deposited on the vapor position coupons. Substantial precipitation of solids was seen at the liquid-vapor interface, where solution was contiually evaporating. Figure 4 shows a photograph of these especially prominent deposits on coupons in the partial liquid position. These deposits were not adherent and were easily dislodged mechanically. The materials deposited on the test coupons were not chemically analyzed.

The coupons were soaked in $1 \mathrm{~N}$ nitric acid at room temperature for 24 hours for decontamination and dissolution of plated-out solids. As Figure 5 and 6 show, deposits were still quite evident following the acid soak. The whitish, plated-out solids remaining after the mechanical cleaning and wiping consisted of thin films less than 0.001 in. thick to a maximum of about 0.003 in. thick. The thickness was determined with an optical microscope whose stage is equipped with a digital micrometer. The heights of an object or material normal to the plane of the specimen can be measured through the micrometer readout of the distance between in-focus images of the top and bottom of the object. Radioactively contaminated specimens were contained in transparent polyethylene bags during measurement.

Whole coupons were assayed by gamma spectroscopy to identify and quantify the radionuclides adhering to them. Gamma scans were performed before and after acid immersion and also after mechanical cleaning and wiping. For Envelope B, the scans showed counts only for cesium-137. The scan results in disintegrations per minute $(\mathrm{dpm})$ are listed in Table 3 . The most contaminated coupons were those in contact with the liquid solution with levels of the order of $5 \times 10^{7} \mathrm{dpm}$ for the 304L coupons and $1 \times 10^{8}$ $\mathrm{dpm}$ for the $316 \mathrm{~L}$ coupons. The acid cleaning produced very modest decontamination factors (defined as the ratio of initial to final contamination levels) of about 4 for the $304 \mathrm{~L}$ coupons and 2 for the $316 \mathrm{~L}$ coupons. However, after mechanical cleaning and wiping with wet laboratory tissues, the final decontamination factors improved to as much as 91 for the highly contaminated coupons. The less- 
contaminated coupons in the vapor and condenser position had varied results from the cleaning steps.

Greater variation is expected at the lower contamination levels. It should be noted that the coupons of each

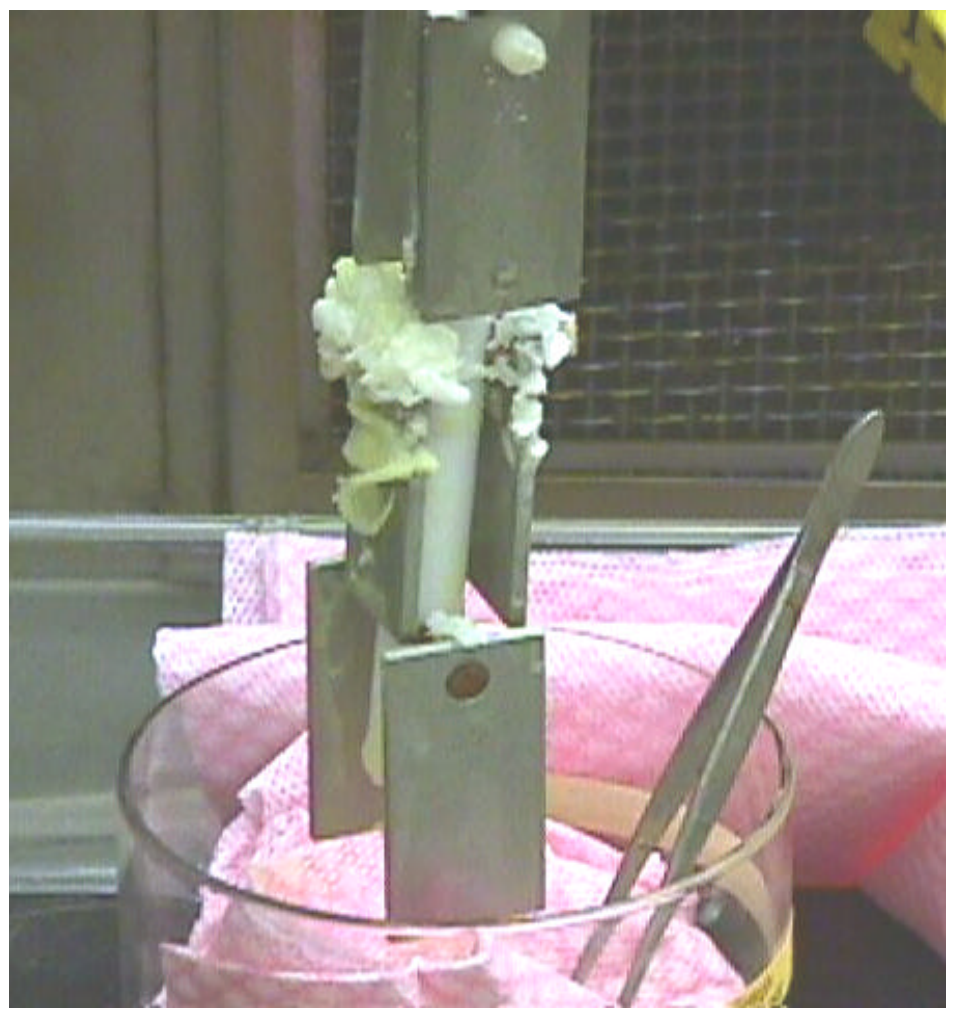

Figure 4 shows 304L stainless steel coupons upon removal from Envelope B solution after 61 days' immersion. This appearance was typical of both envelopes and both stainless steels. The solids attached to the middle pair of coupons (partial liquid position) were especially prominent, although not tightly adherent.

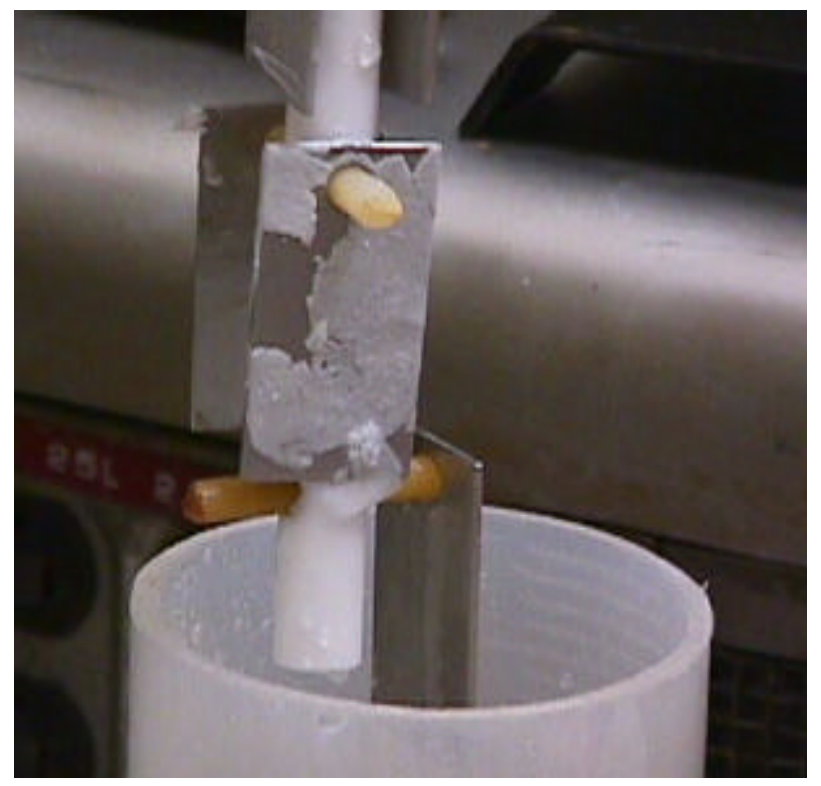

Figure 5. Type $316 \mathrm{~L}$ coupons after acid immersion for 24 hours, with deposits especially retained on the partial-liquid position coupon. 
envelope were cleaned together in a single acid bath, in order to minimize handling of the coupons (the most radioactive coupon, $316 \mathrm{~L}-20$, emitted $396 \mathrm{mrem} /$ hour at contact). This may have allowed contamination to redeposit from one coupon to another.

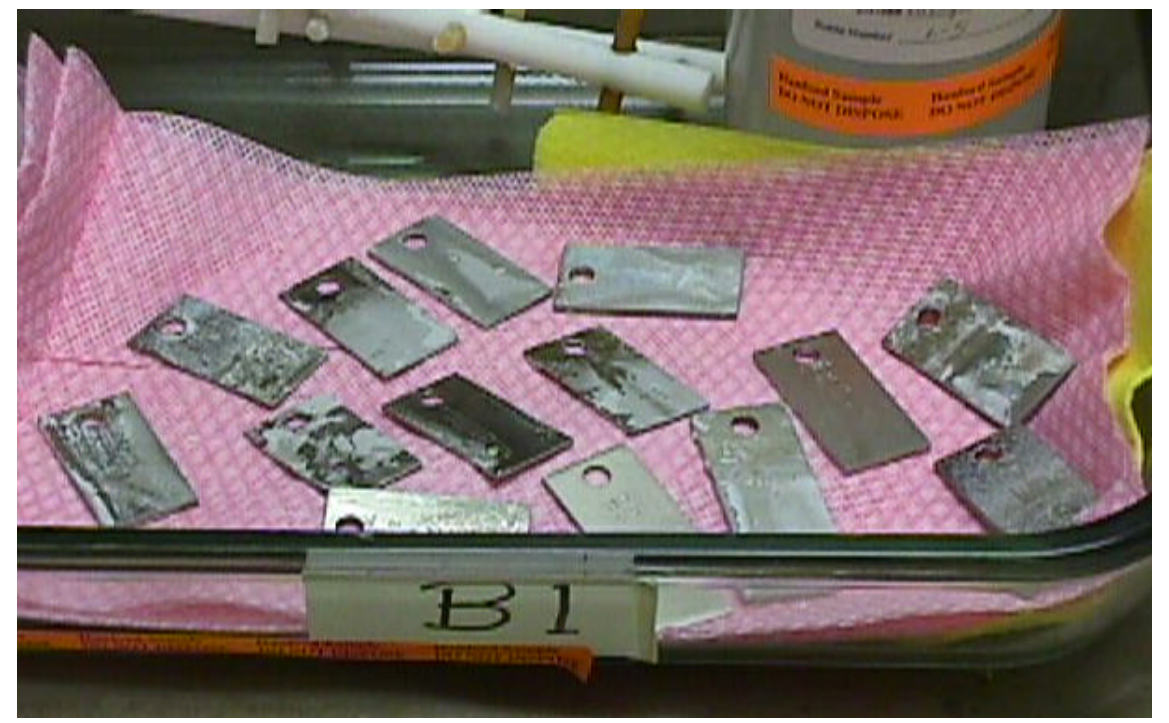

Figure 6. Type 304L and 316L coupons from Envelope B after acid immersion, rinsing, and drying. 
Table 3

Decontamination Results for Envelope B Coupons

(Radionuclide amounts are in units of disintegrations per minute)

\begin{tabular}{lcccccc} 
Coupon No. & Position & $\begin{array}{c}\text { Initial } \\
\text { Cesium-137 }\end{array}$ & $\begin{array}{c}\text { Post Acid } \\
\text { Cesium-137 }\end{array}$ & $\begin{array}{c}\text { Acid Decon. } \\
\text { Factor }\end{array}$ & $\begin{array}{c}\text { After Wiping } \\
\text { Cesium-137 }\end{array}$ & $\begin{array}{c}\text { Final Decon. } \\
\text { Factor }\end{array}$ \\
\hline 304L-21 B1 & Condenser & $1.84 \mathrm{E}+05$ & $7.88 \mathrm{E}+04$ & 2.3 & $9.63 \mathrm{E}+03$ & 19.1 \\
304L-22 B1 & Vapor & $2.40 \mathrm{E}+06$ & $5.02 \mathrm{E}+05$ & 4.8 & $1.73 \mathrm{E}+05$ & 13.9 \\
304L-23 B1 & Vapor & $2.95 \mathrm{E}+06$ & $2.67 \mathrm{E}+05$ & 11.0 & $1.86 \mathrm{E}+04$ & 158.6 \\
304L-24 B1 & Partial Liquid & $3.96 \mathrm{E}+07$ & $1.37 \mathrm{E}+07$ & 2.9 & $1.85 \mathrm{E}+06$ & 21.4 \\
304L-25 B1 & Partial Liquid & $4.27 \mathrm{E}+07$ & $6.47 \mathrm{E}+06$ & 6.6 & $7.95 \mathrm{E}+05$ & 53.7 \\
304L-26 B1 & Full Liquid & $4.53 \mathrm{E}+07$ & $1.14 \mathrm{E}+07$ & 4.0 & $8.75 \mathrm{E}+05$ & 51.8 \\
304L-27 B1 & Full Liquid & $5.25 \mathrm{E}+07$ & $1.59 \mathrm{E}+07$ & 3.3 & $4.60 \mathrm{E}+06$ & 11.4 \\
& & & & & & \\
316L-03 B2 & Condenser & $8.54 \mathrm{E}+04$ & $4.99 \mathrm{E}+04$ & 1.7 & $3.43 \mathrm{E}+03$ & 24.9 \\
316L-04 B2 & Vapor & $2.24 \mathrm{E}+06$ & $2.72 \mathrm{E}+05$ & 8.2 & $5.52 \mathrm{E}+04$ & 40.6 \\
316L-06 B2 & Vapor & $3.74 \mathrm{E}+06$ & $1.56 \mathrm{E}+05$ & 24.0 & $1.63 \mathrm{E}+04$ & 229.4 \\
316L-07 B2 & Partial Liquid & $9.55 \mathrm{E}+07$ & $4.77 \mathrm{E}+07$ & 2.0 & $2.33 \mathrm{E}+06$ & 41.0 \\
316L-08 B2 & Partial Liquid & $1.04 \mathrm{E}+08$ & $5.72 \mathrm{E}+07$ & 1.8 & $1.14 \mathrm{E}+06$ & 91.2 \\
316L-10 B2 & Full Liquid & $1.36 \mathrm{E}+08$ & $3.60 \mathrm{E}+07$ & 3.8 & $2.63 \mathrm{E}+06$ & 51.7 \\
316L-20 B2 & Full Liquid & $1.07 \mathrm{E}+08$ & $5.14 \mathrm{E}+07$ & 2.1 & $1.20 \mathrm{E}+07$ & 8.9
\end{tabular}

The Envelope $\mathrm{C}$ solution as tested was a much less radioactive solution than Envelope B. This difference revealed itself in the overall radiation levels of undetectable to $4 \mathrm{mrem} / \mathrm{hour}$ at contact for the liquidposition Envelope C coupons, compared to the 4 to $396 \mathrm{mrem} / \mathrm{hour}$ fields of Envelope B. Consequently, the cesium-137 levels measured on the Envelope C coupons of either alloy were several orders of magnitude lower than those of Envelope B. In addition to cesium-137, the radionuclides cobalt-60, europium-154, europium-155, and americium-241 were also measured on the Envelope C coupons, and are listed in Table 4. Where detected, these radionuclides had maximum contamination levels of the order of $10^{5} \mathrm{dpm}$. For coupons in the condenser and vapor positions, the table entries are blank where the particular radionuclide was not detected during any gamma scan. Where the radionuclide was detected in one scan of a particular coupon but not another scan, the other scan result is marked 'ND' for 'not detected'. The undefined decontamination factor for that radionuclide is marked with a '-'. As can be seen in Table 4 the vapor and condenser coupons usually had undetectable contamination from any radionuclide. Subsequent contamination detected after acid cleaning can be attributed to cross-contamination in the common acid bath.

Nitric acid immersion decontaminated the liquid-contact Envelope $\mathrm{C}$ coupons to a greater degree than it did the Envelope B coupons, with decontamination factors ranging from 5 to 111. Mechanical cleaning of those coupons increased the decontamination factor to between 10 and 800 . The lowest decontamination factors were associated with coupons whose initial contamination level was already low in the $10^{4} \mathrm{dpm}$ range. 
Table 4

Decontamination Results for Envelope C Coupons

(Radionuclide amounts are in units of disintegrations per minute)

\begin{tabular}{|c|c|c|c|c|c|c|}
\hline Coupon & Position & $\begin{array}{c}\text { Initial } \\
\text { Cesium-137 }\end{array}$ & $\begin{array}{c}\text { Post Acid } \\
\text { Cesium-137 }\end{array}$ & $\begin{array}{l}\text { Acid Decon. } \\
\text { Factor }\end{array}$ & $\begin{array}{l}\text { After Wiping } \\
\text { Cesium-137 }\end{array}$ & $\begin{array}{c}\text { Final Decon. } \\
\text { Factor }\end{array}$ \\
\hline 304L-11 C3 & Condenser & ND & $1.11 \mathrm{E}+03$ & - & $6.49 \mathrm{E}+02$ & - \\
\hline 304L-12 C3 & Vapor & ND & $9.19 \mathrm{E}+02$ & - & $1.20 \mathrm{E}+04$ & - \\
\hline 304L-13 C3 & Vapor & ND & $8.44 \mathrm{E}+02$ & - & $1.33 E+03$ & - \\
\hline 304L-14 C3 & Partial Liquid & ND & $3.21 \mathrm{E}+04$ & - & $2.23 E+03$ & - \\
\hline 304L-15 C3 & Partial Liquid & $1.94 \mathrm{E}+05$ & $1.50 \mathrm{E}+04$ & 12.9 & $2.92 E+03$ & 66.4 \\
\hline $304 L-16$ C3 & Full Liquid & $6.66 \mathrm{E}+05$ & $2.43 \mathrm{E}+05$ & 2.7 & $2.51 \mathrm{E}+03$ & 265 \\
\hline 304L-17 C3 & Full Liquid & $4.39 \mathrm{E}+05$ & $2.46 \mathrm{E}+04$ & 17.8 & $6.64 \mathrm{E}+03$ & 66.1 \\
\hline 316L-11 C4 & condenser & ND & $8.29 \mathrm{E}+02$ & - & $2.80 \mathrm{E}+02$ & - \\
\hline 316L-14 C4 & Vapor & $2.13 E+04$ & $4.90 \mathrm{E}+03$ & 4.3 & $4.47 \mathrm{E}+02$ & 47.7 \\
\hline 316L-15 C4 & Vapor & $9.95 \mathrm{E}+02$ & $2.42 E+03$ & 0.4 & $4.22 \mathrm{E}+02$ & 2.4 \\
\hline 316L-16 C4 & Vapor/Liq. & $2.46 \mathrm{E}+05$ & $1.75 \mathrm{E}+04$ & 14.1 & $1.36 \mathrm{E}+03$ & 181 \\
\hline 316L-17 C4 & Vapor/Liq. & $3.29 E+05$ & $1.80 \mathrm{E}+04$ & 18.3 & $1.82 \mathrm{E}+03$ & 181 \\
\hline 316L-18 C4 & Liquid & $5.59 \mathrm{E}+05$ & $5.02 E+03$ & 111 & $6.99 E+02$ & 800 \\
\hline 316L-19 C4 & Liquid & $4.60 \mathrm{E}+05$ & $3.16 \mathrm{E}+04$ & 14.6 & $7.71 \mathrm{E}+02$ & 597 \\
\hline Coupon & Position & $\begin{array}{c}\text { Initial } \\
\text { Cobalt-60 } \\
\end{array}$ & $\begin{array}{l}\text { Post Acid } \\
\text { Cobalt-60 }\end{array}$ & $\begin{array}{l}\text { Acid Decon. } \\
\text { Factor }\end{array}$ & $\begin{array}{l}\text { After Wiping } \\
\text { Cobalt-60 }\end{array}$ & $\begin{array}{c}\text { Final Decon. } \\
\text { Factor }\end{array}$ \\
\hline $304 \mathrm{~L}-11 \mathrm{C} 3$ & Condenser & & & & & \\
\hline 304L-12 C3 & Vapor & & & & & \\
\hline 304L-13 C3 & Vapor & & & & & \\
\hline 304L-14 C3 & Partial Liquid & $3.67 \mathrm{E}+04$ & $4.38 \mathrm{E}+03$ & 8.4 & $1.03 E+03$ & 35.6 \\
\hline 304L-15 C3 & Partial Liquid & $2.94 \mathrm{E}+04$ & $2.97 \mathrm{E}+03$ & 9.9 & $1.15 \mathrm{E}+03$ & 25.6 \\
\hline 304L-16 C3 & Full Liquid & $7.84 \mathrm{E}+04$ & $1.46 \mathrm{E}+04$ & 5.4 & $5.83 E+02$ & 134 \\
\hline 304L-17 C3 & Full Liquid & $5.43 \mathrm{E}+04$ & $2.47 \mathrm{E}+03$ & 22.0 & $6.71 \mathrm{E}+02$ & 80.9 \\
\hline $316 \mathrm{~L}-11 \mathrm{C} 4$ & Condenser & & & & & \\
\hline 316L-14 C4 & Vapor & ND & $3.54 \mathrm{E}+02$ & - & ND & - \\
\hline 316L-15 C4 & Vapor & & & & & \\
\hline $316 \mathrm{~L}-16 \mathrm{C} 4$ & Partial Liquid & $3.59 \mathrm{E}+04$ & $2.79 \mathrm{E}+03$ & 12.9 & $1.45 \mathrm{E}+03$ & 24.8 \\
\hline 316L-17 C4 & Partial Liquid & $4.16 \mathrm{E}+04$ & $2.80 \mathrm{E}+03$ & 14.9 & $1.32 \mathrm{E}+03$ & 31.5 \\
\hline 316L-18 C4 & Full Liquid & $5.71 \mathrm{E}+04$ & $1.21 \mathrm{E}+03$ & 47.2 & $6.50 \mathrm{E}+02$ & 87.8 \\
\hline 316L-19 C4 & Full Liquid & $5.67 \mathrm{E}+04$ & $2.69 \mathrm{E}+03$ & 21.1 & $7.37 \mathrm{E}+02$ & 76.9 \\
\hline
\end{tabular}


Table 4 continued

Decontamination Results for Envelope C Coupons

\begin{tabular}{|c|c|c|c|c|c|c|}
\hline Coupon & Position & $\begin{array}{c}\text { Initial } \\
\text { Europium- } \\
154\end{array}$ & $\begin{array}{c}\text { Post Acid } \\
\text { Europium- } \\
154\end{array}$ & $\begin{array}{l}\text { Acid Decon. } \\
\text { Factor }\end{array}$ & $\begin{array}{c}\text { After Wiping } \\
\text { Europium- } \\
154\end{array}$ & $\begin{array}{c}\text { Final Decon. } \\
\text { Factor }\end{array}$ \\
\hline 304L-11 C3 & Condenser & & & & & \\
\hline 304L-12 C3 & Vapor & & & & & \\
\hline $304 L-13$ C3 & Vapor & & & & & \\
\hline 304L-14 C3 & Partial Liquid & $2.18 \mathrm{E}+05$ & $3.50 \mathrm{E}+04$ & 6.2 & $1.12 \mathrm{E}+04$ & 19.5 \\
\hline 304L-15 C3 & Partial Liquid & $1.59 \mathrm{E}+05$ & $3.23 E+04$ & 4.9 & 1.37E+04 & 11.6 \\
\hline 304L-16 C3 & Full Liquid & $5.78 E+05$ & $1.32 \mathrm{E}+05$ & 4.4 & $1.26 \mathrm{E}+04$ & 45.9 \\
\hline 304L-17 C3 & Full Liquid & $3.80 \mathrm{E}+05$ & $3.05 E+04$ & 12.5 & $1.22 \mathrm{E}+04$ & 31.1 \\
\hline 316L-11 C4 & condenser & & & & & \\
\hline 316L-14 C4 & Vapor & ND & $2.13 \mathrm{E}+03$ & - & ND & - \\
\hline 316L-15 C4 & Vapor & & & & & \\
\hline $316 L-16$ C4 & Vapor/Liq. & $1.92 \mathrm{E}+05$ & $2.97 \mathrm{E}+04$ & 6.5 & $1.56 \mathrm{E}+04$ & 12.3 \\
\hline 316L-17 C4 & Vapor/Liq. & $2.50 \mathrm{E}+05$ & $4.33 E+04$ & 5.8 & $1.75 \mathrm{E}+04$ & 14.3 \\
\hline $316 \mathrm{~L}-18 \mathrm{C} 4$ & Liquid & $4.43 E+05$ & $3.04 \mathrm{E}+04$ & 14.6 & $1.64 \mathrm{E}+04$ & 27.1 \\
\hline 316L-19 C4 & Liquid & $4.23 E+05$ & $4.53 E+04$ & 9.3 & $1.83 E+04$ & 23.1 \\
\hline Coupon & Position & $\begin{array}{c}\text { Initial } \\
\text { Europium- } \\
155\end{array}$ & $\begin{array}{l}\text { Post Acid } \\
\text { Europium- } \\
\quad 155\end{array}$ & $\begin{array}{l}\text { Acid Decon. } \\
\text { Factor }\end{array}$ & $\begin{array}{l}\text { After Wiping } \\
\text { Eurpopium- } \\
155\end{array}$ & $\begin{array}{c}\text { Final Decon. } \\
\text { Factor }\end{array}$ \\
\hline 304L-11 C3 & Condenser & & & & & \\
\hline $304 L-12$ C3 & Vapor & & & & & \\
\hline $304 L-13$ C3 & Vapor & & & & & \\
\hline $304 L-14$ C3 & Partial Liquid & $1.24 \mathrm{E}+04$ & $1.73 E+04$ & 0.7 & $6.83 E+03$ & 1.8 \\
\hline $304 L-15$ C3 & Partial Liquid & $8.62 E+04$ & 1.67E+04 & 5.2 & $7.61 E+03$ & 11.3 \\
\hline 304L-16 C3 & Full Liquid & $3.12 E+05$ & 4.07E+04 & 7.7 & $6.84 \mathrm{E}+03$ & 45.6 \\
\hline 304L-17 C3 & Full Liquid & $1.98 \mathrm{E}+05$ & $1.47 \mathrm{E}+04$ & 13.5 & $7.19 \mathrm{E}+03$ & 27.5 \\
\hline $316 L-11 \mathrm{C} 4$ & Condenser & & & & & \\
\hline 316L-14 C4 & Vapor & ND & $1.01 \mathrm{E}+03$ & - & ND & - \\
\hline 316L-15 C4 & Vapor & & & & & \\
\hline 316L-16 C4 & Vapor/Liq. & $1.00 \mathrm{E}+05$ & $1.52 \mathrm{E}+04$ & 6.6 & $9.59 \mathrm{E}+03$ & 10.4 \\
\hline 316L-17 C4 & Vapor/Liq. & $1.32 \mathrm{E}+05$ & $2.42 \mathrm{E}+04$ & 5.5 & $1.15 \mathrm{E}+04$ & 11.5 \\
\hline $316 \mathrm{~L}-18 \mathrm{C} 4$ & Liquid & $2.48 \mathrm{E}+05$ & $1.76 \mathrm{E}+04$ & 14.1 & $9.82 \mathrm{E}+03$ & 25.3 \\
\hline $316 \mathrm{~L}-19 \mathrm{C} 4$ & Liquid & $2.10 \mathrm{E}+05$ & $2.28 \mathrm{E}+04$ & 9.2 & $1.16 \mathrm{E}+04$ & 18.1 \\
\hline
\end{tabular}


Table 4 continued

Decontamination Results for Envelope C Coupons

\begin{tabular}{|c|c|c|c|c|c|c|}
\hline Coupon & Location & $\begin{array}{c}\text { Initial } \\
\text { Amercium- } \\
241\end{array}$ & $\begin{array}{l}\text { Post Acid } \\
\text { Americium- } \\
241\end{array}$ & $\begin{array}{l}\text { Acid Decon. } \\
\text { Factor }\end{array}$ & $\begin{array}{l}\text { After Wiping } \\
\text { Amercium- } \\
241\end{array}$ & $\begin{array}{c}\text { Final Decon. } \\
\text { Factor }\end{array}$ \\
\hline $304 \mathrm{~L}-11 \mathrm{C} 3$ & Condenser & & & & & \\
\hline $304 \mathrm{~L}-12 \mathrm{C} 3$ & Vapor & & & & & \\
\hline 304L-13 C3 & Vapor & & & & & \\
\hline $304 L-14$ C3 & Vapor/Liq. & $9.49 \mathrm{E}+04$ & $1.27 \mathrm{E}+04$ & 7.5 & ND & - \\
\hline $304 L-15$ C3 & Vapor/Liq. & ND & $1.44 \mathrm{E}+04$ & - & $6.40 \mathrm{E}+03$ & - \\
\hline 304L-16 C3 & Liquid & $2.33 E+05$ & $2.06 \mathrm{E}+04$ & 11.3 & $7.00 \mathrm{E}+03$ & 33.3 \\
\hline 304L-17 C3 & Liquid & ND & $1.18 \mathrm{E}+04$ & - & $6.76 \mathrm{E}+03$ & - \\
\hline $316 \mathrm{~L}-11 \mathrm{C} 4$ & Condenser & & & & & \\
\hline $316 L-14$ C4 & Vapor & & & & & \\
\hline $316 \mathrm{~L}-15 \mathrm{C} 4$ & Vapor & & & & & \\
\hline $316 \mathrm{~L}-16 \mathrm{C} 4$ & Vapor/Liq. & $9.36 \mathrm{E}+04$ & $1.48 \mathrm{E}+04$ & 6.3 & $7.40 \mathrm{E}+03$ & 12.6 \\
\hline 316L-17 C4 & Vapor/Liq. & $9.13 E+04$ & $2.22 \mathrm{E}+04$ & 4.1 & $1.17 \mathrm{E}+04$ & 7.8 \\
\hline $316 \mathrm{~L}-18 \mathrm{C} 4$ & Liquid & $1.39 E+05$ & $1.55 \mathrm{E}+04$ & 9.0 & $8.70 \mathrm{E}+03$ & 16.0 \\
\hline $316 \mathrm{~L}-19 \mathrm{C} 4$ & Liquid & $1.76 \mathrm{E}+05$ & $2.30 \mathrm{E}+04$ & 7.7 & $1.17 \mathrm{E}+04$ & 15.0 \\
\hline
\end{tabular}

The high decontamination factors and the overall low level of contamination of the cleaned Envelope $\mathrm{C}$ coupons were revealed visually in the absence of the substantial deposits of the type seen on Envelope B coupon 316L-20. Envelope C coupons were generally shiny with some areas of staining and few slight plated-out solids.

\section{CONCLUSIONS}

Long-term immersion tests of type 304L and 316L stainless steel in pretreated Envelope B and C solutions indicate that these alloys will not experience any significant corrosion in handling these solutions. However, the corrosion effects from cyclic accumulation of deposits followed by cleaning need to be evaluated to confirm selection of these materials. The tests exposed flat coupons to full-liquid immersion, to partial-liquid immersion (coupons suspended at the liquid-vapor interface), and to vapor above the hot $\left(100^{\circ} \mathrm{C}\right)$ liquid. Measured corrosion rates were less than 0.001 in. per year. Most coupons showed weight gains due to plated-out solids, and so were not available for corrosion rate measurements based on weight loss. However, optical microscopy did show essentially pristine surface conditions (sharp, prominent finishing marks) on all coupons. No evidence of general or localized corrosion was seen under microscopic examination.

Hard white solid films plated out on the coupons of both steels that were in contact with liquid. These films were much more pronounced in the Envelope B coupons compared with the Envelope C coupons, and in Envelope B they were not completely removed through 24 hours' immersion in $1 \mathrm{~N}$ nitric acid at room temperature. Irregular patches of the films up to 0.003 in. thick remained on the Envelope B coupons after acid cleaning and mechanical cleaning. However, the acid cleaning was very effective with the Envelope $\mathrm{C}$ coupons, which were free of all but slight residual plate-out after cleaning. Gamma spectroscopy scans revealed that the acid cleaning step decontaminated the most contaminated Envelope B coupons by a factor of 2 to 7. Mechanical cleaning improved the decontamination factors up to 90 for Envelope B coupons that had been in liquid contact and 800 for the Envelope C coupons. After final cleaning, Envelope B coupons retained 2 to 5 orders of magnitude more cesium-137 than Envelope C coupons. 


\section{REFERENCES}

1. M. E. Johnson, "Materials Corrosion, Erosion and Plate-Out Test Specification", TSP-W375-99-

00001, revision 2, BNFL Inc., Richland, Washington.

2. M. J. Danielson et al., "Active Waste Materials Corrosion and Decontamination Tests", PNWD-3051, BNFL-RPT-039, revision 0, August 2000, Pacific Northwest National Laboratory, Richland, Washington.

3. P. E. Zapp, "Materials Corrosion and Plate-Out Test", BNF-003-99-0078, Rev. 1, August 19, 1999.

4. N. M. Hassan, D. J. McCabe, W. D. King, and M. L. Crowder, "Small-Scale Ion Exchange Removal Of Cesium And Technetium From Envelope B Hanford Tank 241-AZ-102", WSRC-TR-2000-00419, SRT-RPP-2000-00036, January 16, 2001.

5. M.S. Hay, "Characterization of Tank 241-AZ-102”, BNF-003-98-0249.

6. C. A. Nash et al., "Entrained Solids, Strontium - Transuranic Precipitation And Cross-flow Filtration Of An102 Small C", WSRC-TR-2000-00341 (SRT-RPP-2000-00003), August 2000, Westinghouse Savannah River Company, Aiken South Carolina.

\section{DISTRIBUTION:}

C. R. Wolfe, WSRC, 773-A

N. C. Iyer, WSRC, $773-41 \mathrm{~A}$

G. T. Chandler, WSRC, 773-A

W. L. Tamosaitis, WSRC, 773-A

S. T. Wach, WSRC, 773-42A

D. B. Burns, WSRC, 786-5A

C. T. Randall, WSRC, 773-42A

T. B. Calloway, Jr., WSRC, 704-1T

H. H. Saito, WSRC, 773-42A

D. P. Lambert, WSRC, 704-1T

C. A. Nash, WSRC, 773-42A

C. L. Crawford, WSRC, 773-41A

K. J. Imrich, WSRC, 773-A

STI, 703-43A (4) 